\title{
Labour market and employment policies in Macedonia
}

\begin{abstract}
This analysis of the labour market is based on evidence of the structure of employment/unemployment rates, age, education, type of business and activity rates for the population capable of working. Macedonia has one of the highest unemployment rates in Europe, with a disproportionate effect on young people who do not have the skills the market requires. The situation has been improving recently, but slowly: the effects of a large grey economy whose social component provides benefit (and in which young people are also found disproportionately); while the mismatch between skills and labour market requirements does not only affect young people. The government has embarked on a programme of radical reform of the education system with a view to increasing the output of students with occupationally-relevant skills required by modern employers, although it is too early yet to talk of results. The authors also outline the several active labour policy initiatives being pursued by the government which have the aim of modernising the labour market.
\end{abstract}

Keywords: labour force, labour market, youth unemployment, 'brain drain', education reforms, grey economy, employment rate, long-term unemployment, new skills, active and passive labour policies, labour institutions

\section{Introduction}

In the last two decades, unemployment has been one of the key economic and social issues that Macedonia has been facing. Basically, Macedonia has gone through a rough patch during the transition period, which has resulted in the closure of many businesses, companies, factories, etc. This led to many workers losing their jobs. Furthermore, the labour market did not have the capacity to absorb this surplus workforce, mainly because of the lack of job creation and a shortage of the skills needed by the job market.

In most of the period, Macedonia had a weak economic performance, with low GDP growth rates, low levels of investment, etc. Today, Macedonia has almost the same level of GDP as it did twenty years ago. Several events have contributed to this unfortunate situation, such as the trade embargo imposed by neighbouring Greece, weak structural reforms and a refugee crisis in Macedonia caused firstly by the Kosovo war events and then the military conflict in Macedonia in 2001. Due to this, many negative effects emerged, such as unemployment, poverty, migration, regional disparities, the grey economy and so on.

Approximately one-third of the population in Macedonia is considered to be poor. Furthermore, this situation has a very negative impact on the budget considering the costs of social transfers, less income from taxes, etc. 
However, taking the last five years into account, a number of policies and measures have been introduced in order to improve the economic situation in Macedonia. Even though the results are not particularly satisfactory, the efforts are obvious.

In addition, one must emphasise that Macedonia is a country with high macroeconomic stability and one which is fully compliant with the Maastricht criteria. The past fifteen years have been characterised by low inflation rates, a budget deficit below $3 \%$ (except in 2001, due to the ethnic conflict in Macedonia), public debt at a level lower than $60 \%$ and a stable currency. This provides excellent preconditions for economic growth and investment promotion which, of course, leads to higher employment.

\section{Latest macroeconomic developments}

According to the latest GDP data, in the first quarter of 2011 economic activity registered a positive growth rate of $5.1 \%$ on an annual basis. Such growth has not been evidenced since $2008(5.8 \%)$; that is, prior to the global financial crisis. The main carriers of the increased economic activity in the country were construction $(21.2 \%)$ and industry (13.7\%). After five months in the positive zone, however, industrial production in June registered a negative annual growth of $-1.8 \%$. The main contributors to the fall were: the petroleum industry $(-84.8 \%)$; electricity $(-33.5 \%)$; and fabricated metal products $(-35.9 \%)$. At the same time, positive growth was registered in: electrical equipment (193.5\%); tobacco products (47.9\%); and clothing apparel (19.9\%). An annual decrease was evident in sixteen out of 26 industries, representing $54.23 \%$ of the total volume of industrial production. According to the estimation of the managers of business entities in manufacturing industry, the business environment in the first quarter of 2011 was assessed as more favourable compared to the same period in 2010.

Exports in May 2011 reached $€ 260.9 \mathrm{~m}$, which was $43.4 \%$ higher on an annual basis (i.e. compared to May 2010). The most significant products were: supported catalysts, with precious metal or precious metal compounds as the active substance; iron and steel products; clothes; as well as ferrous-nickel and petroleum oil preparations. Total imports in May reached $€ 387.6 \mathrm{~m}$, which was $32.2 \%$ higher compared to the previous year. Here, the most significant products were: platinum and platinum alloys; colloidal precious metals; amalgams of precious metals; crude petroleum oils; and motor vehicles for the transport of people. Thus, the trade volume amounted to $€ 648.5 \mathrm{~m}$, which was $36.5 \%$ higher relative to the first quarter of 2010 . The export/import coverage ratio increased to $60.7 \%$. However, the total trade deficit for the first five months reached $€ 782 \mathrm{~m}$, or $15 \%$ higher than the respective period in 2010 .

The current account balance in April registered a deficit of $€ 41.3 \mathrm{~m}$, which was slightly higher than in March and almost the same as in April 2010. The higher trade deficit was neutralised by higher private transfers.

In June, no changes in monetary instruments were registered. However, the real interest rate increased to $-0.1 \%$. The money market interest rate decreased by two base points, reaching a level of $2.1 \%$. The fiscal deficit in June widened to $€ 125.4 \mathrm{~m}$, or $1.8 \%$ of GDP, compared to $1.5 \%$ in the previous month. On an annual level, the budget deficit in the same period of the previous year was $1.5 \%$ of GDP.

The index of the number of employees in industry in June, in comparison with the same month of the previous year, was 103.3. The number of employees in mining and 
quarrying increased by $2.8 \%$; in manufacturing industry, it increased by $1.8 \%$; and in electricity, gas, steam and the supply of air conditioning, it was $4.2 \%$ higher. The index of the number of employees in industry for January-June 2011, in comparison with January-June 2010, was 102.2.

This article highlights the current labour market situation in Macedonia, explores the policies being implemented in response and provides some consideration as to what might work better in the future.

\section{Labour market situation in Macedonia}

Macedonia has one of the highest unemployment rates in Europe. Several of the reasons mentioned above contribute to this unfortunate situation. In 2006, the unemployment rate was $36 \%$. Table 1 shows a positive trend with respect to a decrease in the unemployment rate which, at the end of 2010 , amounted to $30.9 \%$. Based on the data, there is an obvious improvement, but the unemployment rate is still too high and is far from satisfactory.

However, it is important to notice that this number is not real, considering the high level of the grey economy in the country. We cannot be sure, but some calculations state that the real unemployment rate is between $20 \%$ and $25 \%$, which means that approximately one-quarter of the unemployed are actually in work and receiving a certain level of income. The grey economy is a great problem to the Macedonian economy. It reduces public revenues and negatively affects competitiveness. On the other hand, one of the reasons why this phenomenon has been tolerated is its social component. This problem needs to be addressed appropriately but, apparently, the right solution has not yet been found.

Regarding the employment rate, this shows an increase; however, there is no significant increase in terms of the change of the number of employed people compared to the previous year.

Table 1 - Labour force and employment/unemployment rates, 2006-2010

\begin{tabular}{|l|c|c|c|c|c|}
\hline & $\mathbf{2 0 0 6}$ & $\mathbf{2 0 0 7}$ & $\mathbf{2 0 0 8}$ & $\mathbf{2 0 0 9}$ & $\mathbf{2 0 1 0 / I V}$ \\
\hline Labour force & 891678 & 907139 & 919424 & 928774 & 954928 \\
\hline Employed & 570404 & 590234 & 609015 & 629901 & 659557 \\
\hline Unemployed & 321274 & 316905 & 310409 & 298873 & 295371 \\
\hline Employment rate (\%) & 35.2 & 36.2 & 37.3 & 38.4 & 39.9 \\
\hline Unemployment rate (\%) & 36.0 & 34.9 & 33.8 & 32.2 & 30.9 \\
\hline Change (employed people) & $4.60 \%$ & $3.50 \%$ & $3.20 \%$ & $3.40 \%$ & N/A \\
\hline Change (unemployed people) & $-0.80 \%$ & $-1.40 \%$ & $-2.00 \%$ & $-3.70 \%$ & N/A \\
\hline
\end{tabular}

The 'change' rows show the change in the number of people compared to the previous year

Source: State Statistical Office, Republic of Macedonia. 
Figure 1 - Employment and unemployment rates, 2006-2010

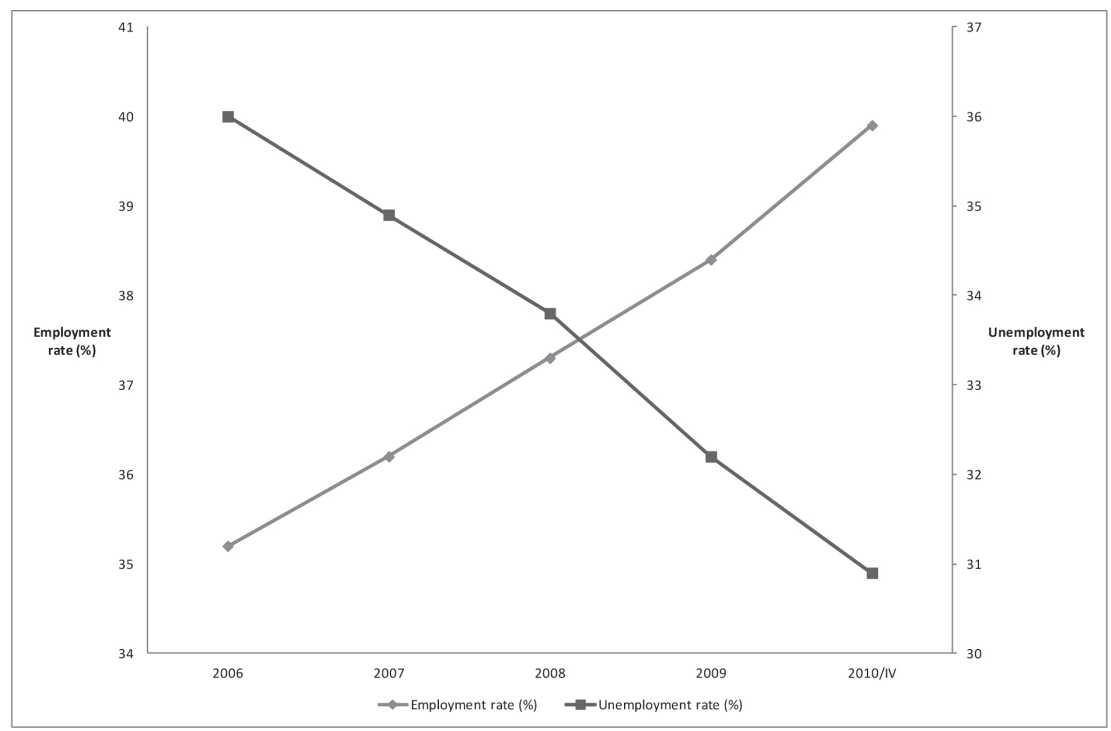

When looking at the data for 2006, we can see that, even though Macedonia started its transition period fifteen years ago, there are still huge numbers of the employed who are part of the public, state or collective sector. However, there is a positive trend showing that, in five years, the number of people employed in the private sector has increased by around 120000 workers, which is an increase of roughly $30 \%$. In an analysis of the fourth quarter of 2010, we found that two-thirds of those employed who are part of the private sector are workers related to agriculture or manufacturing. This is an excellent indication of the structure of the Macedonian economy.

Table 2 - Employees of organisations by type of ownership, 2006-2010

\begin{tabular}{|l|c|c|c|c|c|}
\hline & $\mathbf{2 0 0 6}$ & $\mathbf{2 0 0 7}$ & $\mathbf{2 0 0 8}$ & $\mathbf{2 0 0 9}$ & $\mathbf{2 0 1 0 / I V}$ \\
\hline Employed & 570405 & 590234 & 609015 & 629901 & 659557 \\
\hline Private ownership & 376867 & 407154 & 434818 & 463683 & 494793 \\
\hline Other ownership* & 193538 & 183080 & 174197 & 166218 & 164764 \\
\hline $\begin{array}{l}\text { Private ownership/ } \\
\text { Total employed }\end{array}$ & $66.07 \%$ & $68.98 \%$ & $71.40 \%$ & $73.61 \%$ & $75.02 \%$ \\
\hline $\begin{array}{l}\text { Other ownership/ Total } \\
\text { employed }\end{array}$ & $33.93 \%$ & $31.02 \%$ & $28.60 \%$ & $26.39 \%$ & $24.98 \%$ \\
\hline
\end{tabular}

* Other ownership: social, mixed, collective, state.

Source: State Statistical Office, Republic of Macedonia. 
It is interesting to see the graph below, which reflects the data in Table 2, and to notice the upwards movement of the private sector compared to the state or collective sector. It is to be hoped that this trend will continue at a faster pace, and that the private sector will grow while the public sector shrinks.

Figure 2 - Employees in firms under private ownership and all other forms, 2006-2010

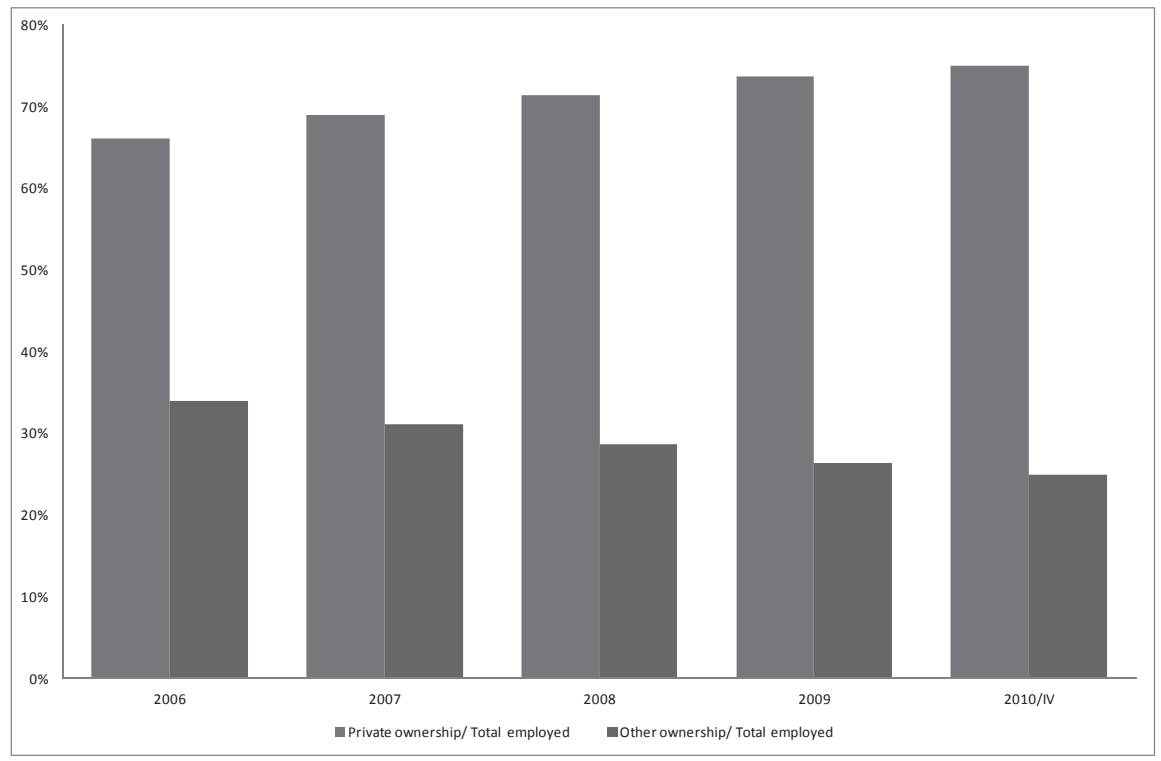

If we consider those employed in terms of gender, we can see that, in the last five years, there have not been significant changes in the structure of the labour market. Around $60 \%$ of those employed are men, while $40 \%$ are women. One of the factors in this situation is what we have described above in relation to Table 2, which is the structure of the Macedonian economy by ownership: two-thirds of those employed in the private sector do some kind of work related either to agriculture or to manufacturing.

With respect to gender policies, one of the problems that the authorities need to work on is the social exclusion of women in rural areas and in ethnic communities: certain measures need to be undertaken to improve this situation. Furthermore, in some cases, in job vacancy announcements, one can see that the employer has outlined the gender of the candidate that the company is looking for, and this is usually a job position for which the gender of the candidate is not important. This issue needs to be addressed appropriately. 
Table 3 - Employed population, by gender (15 years of age and over)

\begin{tabular}{|l|c|c|c|c|c|}
\hline & $\mathbf{2 0 0 6}$ & $\mathbf{2 0 0 7}$ & $\mathbf{2 0 0 8}$ & $\mathbf{2 0 0 9}$ & $\mathbf{2 0 1 0 / I V}$ \\
\hline Employed & 570405 & 590234 & 609015 & 629901 & 659557 \\
\hline Men & 351974 & 358835 & 373483 & 389332 & 401884 \\
\hline Women & 218431 & 231399 & 235532 & 240569 & 257673 \\
\hline Men/Total employed & $61.70 \%$ & $60.80 \%$ & $61.30 \%$ & $61.80 \%$ & $60.90 \%$ \\
\hline Women/Total employed & $38.30 \%$ & $39.20 \%$ & $38.70 \%$ & $38.20 \%$ & $39.10 \%$ \\
\hline
\end{tabular}

Source: State Statistical Office, Republic of Macedonia.

When looking at unemployment rates by age, we can see that the highest unemployment rates are found amongst young people. The explanation for this situation can be found in the lack of a match between the labour market and the education system. In addition, many young people are considered to be part of the grey economy. This has a very negative impact, considering the potential of young people to be able to contribute to the economic development of the country. In recent years, competition in the education sector has significantly increased and, in that sense, the number of students has risen. This may well be one of the reasons why the unemployment rate for people aged between 15 and 24 years has decreased in the last few years. On the other hand, the higher number of enrolled students may be justified by the difficulties young people are facing while searching for jobs.

The chart below refers to 2010/IV and clearly depicts the data provided in Table 4. We can see how large a portion young people are in the overall pool of unemployed people.

\section{Table 4 - Unemployment rates of the population, by age group}

\begin{tabular}{|l|c|c|c|c|}
\hline Year/Age & $\mathbf{1 5 - 2 4}$ & $\mathbf{2 5 - 4 9}$ & $\mathbf{5 0 - 6 4}$ & over 64 \\
\hline 2006 & 59.8 & 34.0 & 28.4 & 3.2 \\
\hline 2007 & 57.7 & 32.9 & 28.5 & 3.2 \\
\hline 2008 & 56.4 & 31.6 & 28.0 & 8.8 \\
\hline 2009 & 55.1 & 30.3 & 25.9 & 12.3 \\
\hline $2010 / \mathrm{IV}$ & 50.5 & 30.3 & 24.7 & 5.5 \\
\hline
\end{tabular}

Source: State Statistical Office, Republic of Macedonia. 
Figure 3 - Unemployment rates, by age (2010/IV)

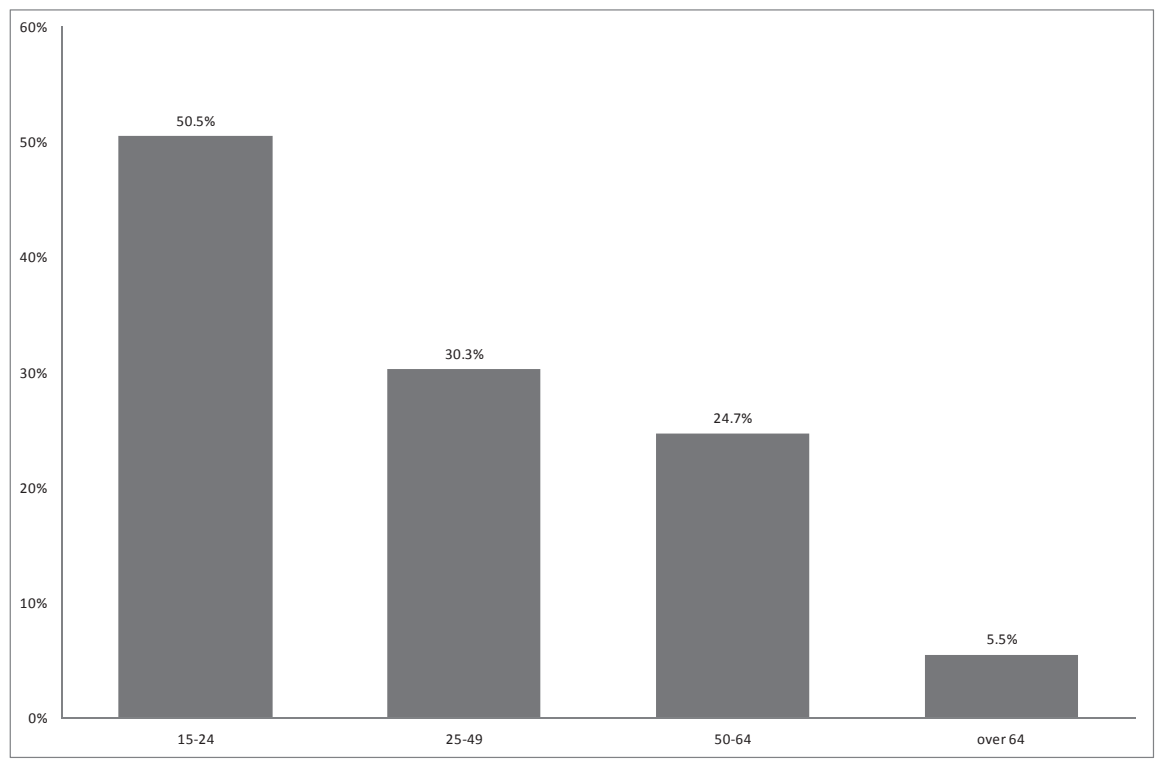

Most of those who are unemployed in Macedonia are people with secondary education and lower. This is a result of economic restructuring and an increasing demand for skilled, as opposed to unskilled, workers. Many among the long-term unemployed are people with skills which are no longer required on the job market. This situation can be improved by the establishment of proper and adequate education and pre-qualification programmes.

In 2006 , only $6.82 \%$ of unemployed people had a university-level education. Looking back these five years, we can see that there were almost twice as many unemployed people in 2010 who had a university-level education than there had been in 2006. One of the main reasons for this is the increase in the number of students who have graduated. According to the Macedonian State Statistical Office, the number of students who graduated from higher education schools and faculties in 2008 increased by $29.6 \%$ on the 2007 level.

With respect to skills matching, most unemployed people are not informed about the skills and professions required on the job market. In addition, the general picture is that many people are not sufficiently flexible regarding pre-qualification programmes and training, especially when it comes to people at the age of forty and above. However, this does not change the situation that pre-qualification programmes are needed in order to improve the matching of skills with the demand for labour and to encourage people to respond to the more general requirements of the contemporary labour market. 
Table 5 - Percentage of unemployed people, by educational level, 2006-2010

\begin{tabular}{|l|c|c|c|c|c|}
\hline & \multicolumn{5}{|c|}{ Structure of total unemployed persons } \\
\cline { 2 - 6 } & $\mathbf{2 0 0 6}$ & $\mathbf{2 0 0 7}$ & $\mathbf{2 0 0 8}$ & $\mathbf{2 0 0 9}$ & $\mathbf{2 0 1 0 / I V}$ \\
\hline Without education & 1.69 & 1.70 & 1.47 & 0.78 & 0.22 \\
\hline $\begin{array}{l}\text { Incomplete primary and lower } \\
\text { secondary education }\end{array}$ & 4.99 & 4.66 & 4.57 & 3.51 & 2.65 \\
\hline $\begin{array}{l}\text { Primary and lower secondary } \\
\text { education }\end{array}$ & 30.21 & 29.50 & 31.46 & 30.18 & 26.07 \\
\hline 3 years of secondary education & 16.00 & 15.28 & 13.37 & 13.44 & 14.43 \\
\hline 4 years of secondary education & 38.13 & 39.34 & 39.37 & 40.60 & 42.20 \\
\hline Higher education & 2.16 & 2.09 & 2.01 & 1.66 & 1.76 \\
\hline University level education & 6.82 & 7.43 & 7.76 & 9.83 & 12.41 \\
\hline
\end{tabular}

Source: State Statistical Office, Republic of Macedonia.

Figure 4 - Percentage of unemployed people, by level of education (2009)

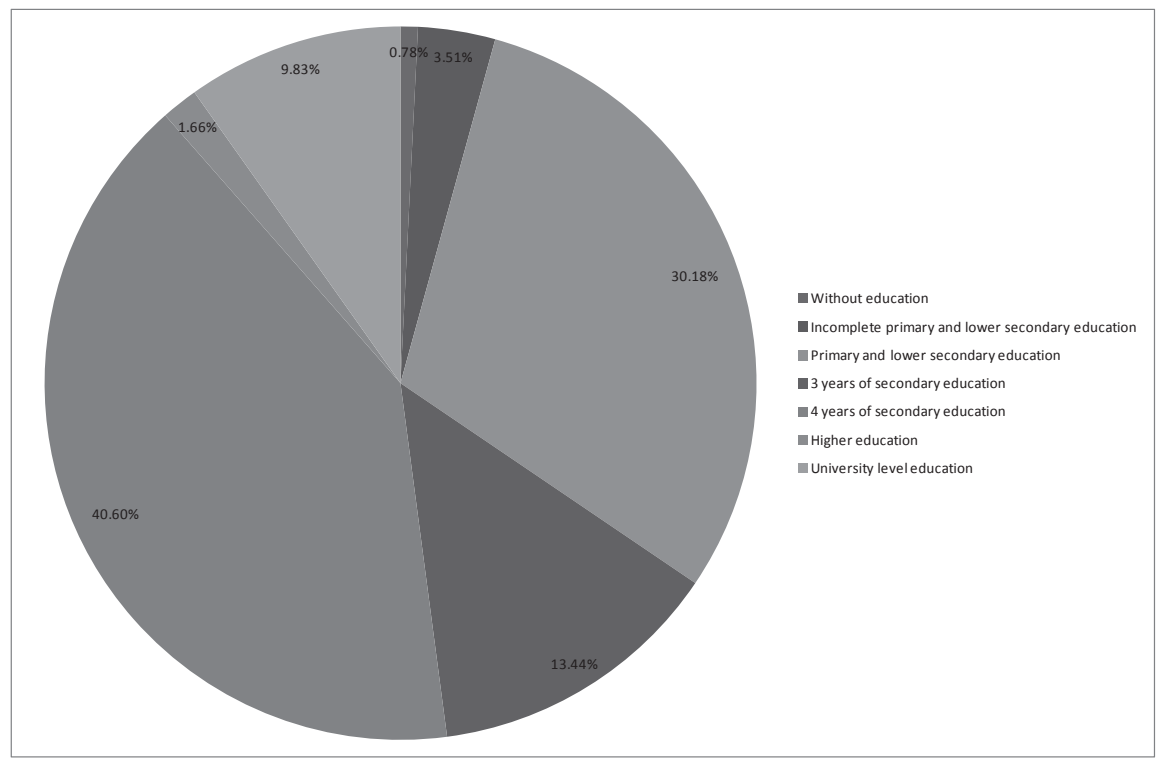

With respect to the physical geography of Macedonia, there are eight regions subdivided at NUTS3 level. The image is quite polarised. Most economic activity is carried out in Skopje, the capital city. Table 6 confirms this picture in terms of the numbers of the population of working age living in the Skopje region. However, the picture is 
complicated in that there are many people who are part of the workforce in Skopje although officially their home address is in one of the other regions. In 2007, almost $50 \%$ of gross domestic product belonged to the Skopje region while, in the same year, the north-east region contributed little more than $4 \%$ of national GDP.

This explains the data below, which shows that the unemployment rate in the northeast region is an enormous $58 \%$. The lowest unemployment rate is reported in the south-east region, mainly because of the increased level of investment and the number of people who are involved in agriculture. The eastern region is also characterised by low unemployment; however, the reasons for this can be attributed to this region having the highest level of emigration.

Table 6 - Activity rates for the population (aged 15 and over, 2008)

\begin{tabular}{|l|c|c|c|c|}
\hline Region & $\begin{array}{c}\text { Size of population of } \\
\text { working age (no.) }\end{array}$ & Activity rate & $\begin{array}{c}\text { Employment } \\
\text { rate }\end{array}$ & $\begin{array}{c}\text { Unemploy- } \\
\text { ment rate }\end{array}$ \\
\hline Vardar & 122138 & 57.9 & 32.7 & 43.6 \\
\hline East & 152504 & 59.2 & 47.4 & 20.0 \\
\hline South-west & 176191 & 55.5 & 33.7 & 39.3 \\
\hline South-east & 141859 & 70.5 & 62.3 & 11.7 \\
\hline Pelagonia & 195363 & 63.6 & 41.6 & 34.5 \\
\hline Polog & 234365 & 43.9 & 32.3 & 26.4 \\
\hline North-east & 137773 & 59.5 & 25.0 & 58.0 \\
\hline Skopje & 473148 & 53.1 & 33.3 & 37.3 \\
\hline
\end{tabular}

Source: State Statistical Office, Republic of Macedonia. 
Figure 5 - Unemployment rate (\%), by region (15 years and over, 2008)

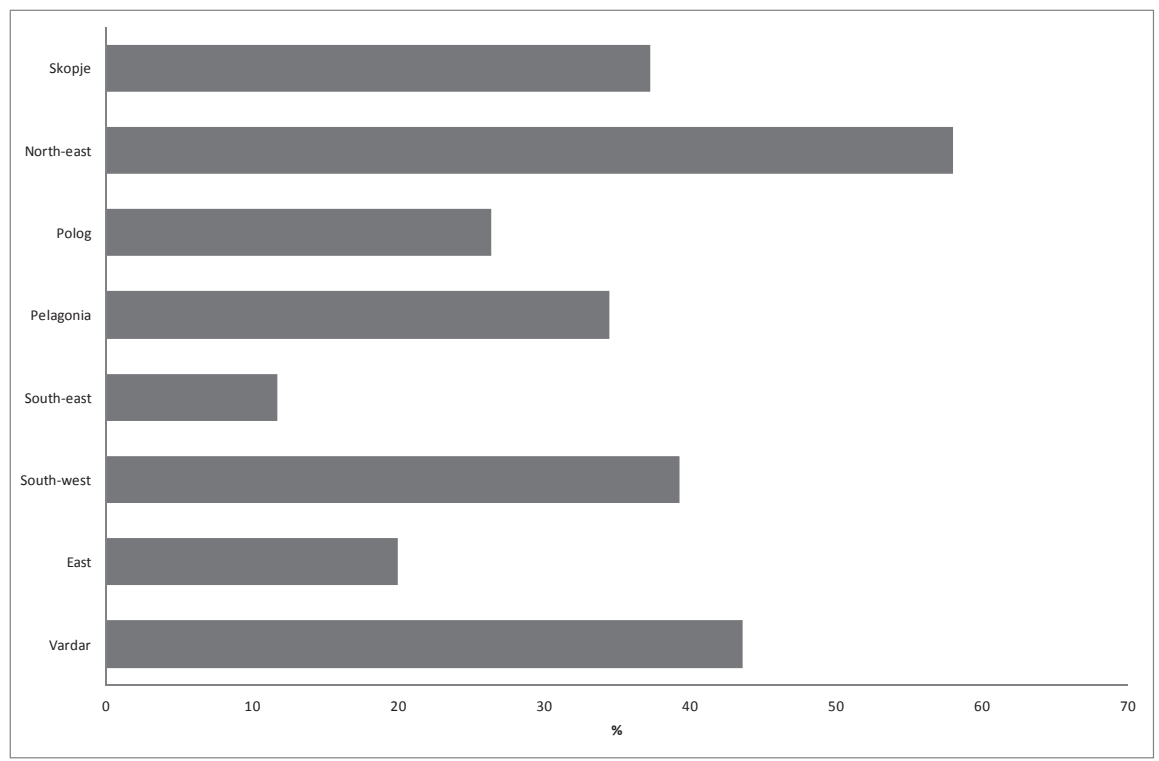

\section{Employment policies}

\section{Fiscal and taxation policy}

Since 2006, the government of Macedonia has made certain changes with respect to fiscal and taxation policy. Until 2007, Macedonia was a country with a progressive taxation system. The tax rate on profits was $15 \%$, while the personal income tax rate was $15 \%, 18 \%$ and $24 \%$. Since then, tax reforms have been implemented as part of measures for improving the business climate in the country and attracting investment. A flat-rate tax system was introduced and the tax rate on profits and the personal income tax rate were decreased to $12 \%$. In 2008, these tax rates were further reduced to $10 \%$. Additionally, a zero tax on retained earnings was introduced. This has proved to be a successful measure, considering that there has not been a loss to public revenue.

There are also plenty of highly attractive incentives offered to companies interested in investing in Technological Industrial Development Zones. In the past few months, interest in investing in these zones has increased.

Unlike many other countries having difficulties with public debt and a budget deficit, Macedonia has a disciplined fiscal policy, with a budget deficit below $3 \%$ and a level of public debt (in March 2010) standing at $32.7 \%$ of GDP. Furthermore, in order to stimulate the private sector and increase employment, the government has decided to decrease social, health and pensions contributions from $32 \%$ to $22 \%$ (in several phases by 2011). 
Capital expenditures for 2011 are projected at $5.1 \%$ of GDP, which represents an increase of around $30 \%$ compared with last year's amount. All of these measures were introduced with the objective of increasing economic growth, improving living standards and decreasing the high level of unemployment.

Table 7 shows that, starting from 2005, Macedonia has had decent results relating to growth in GDP. Up to 2008, growth rates were around $5 \%$, reaching a peak in 2007 when the growth rate reached $6.1 \%$. This only barely matched the $6 \%$ to $8 \%$ which had been expected, but the outcome was, nevertheless, satisfactory. This positive trend was disrupted because of the global economic crisis and, in that context, the GDP growth rate fell to $-0.9 \%$ in 2009 . However, looking at some of the other economies in south-east Europe (for example, Croatia: $-5.8^{1}$ GDP growth rate; Romania $-7.1 \%$; and Bulgaria $-5.0 \%$ ), this outcome is not too bad.

What is interesting to note is that, in 2009, Macedonia was struck by the downturn in the global economy (if we take into consideration the real GDP growth rate) but, in the same year, a decrease was recorded in the unemployment rate. Bearing this in mind, one can conclude that, during 2009, the workforce that was negatively affected by global events were mostly those engaged in the grey economy.

Table 7 - Gross Domestic Product, 2005-2009

\begin{tabular}{|l|c|c|c|c|c|}
\hline & $\mathbf{2 0 0 5}$ & $\mathbf{2 0 0 6}$ & $\mathbf{2 0 0 7}$ & $\mathbf{2 0 0 8}$ & $\mathbf{2 0 0 9}$ \\
\hline GDP real growth rate (\%) & 4.4 & 5.0 & 6.1 & 5.0 & -0.9 \\
\hline
\end{tabular}

Source: Labour Force Survey, 2009, State Statistical Office, Republic of Macedonia

1 Preliminary data. 
Figure 6 - GDP, 2005-2009

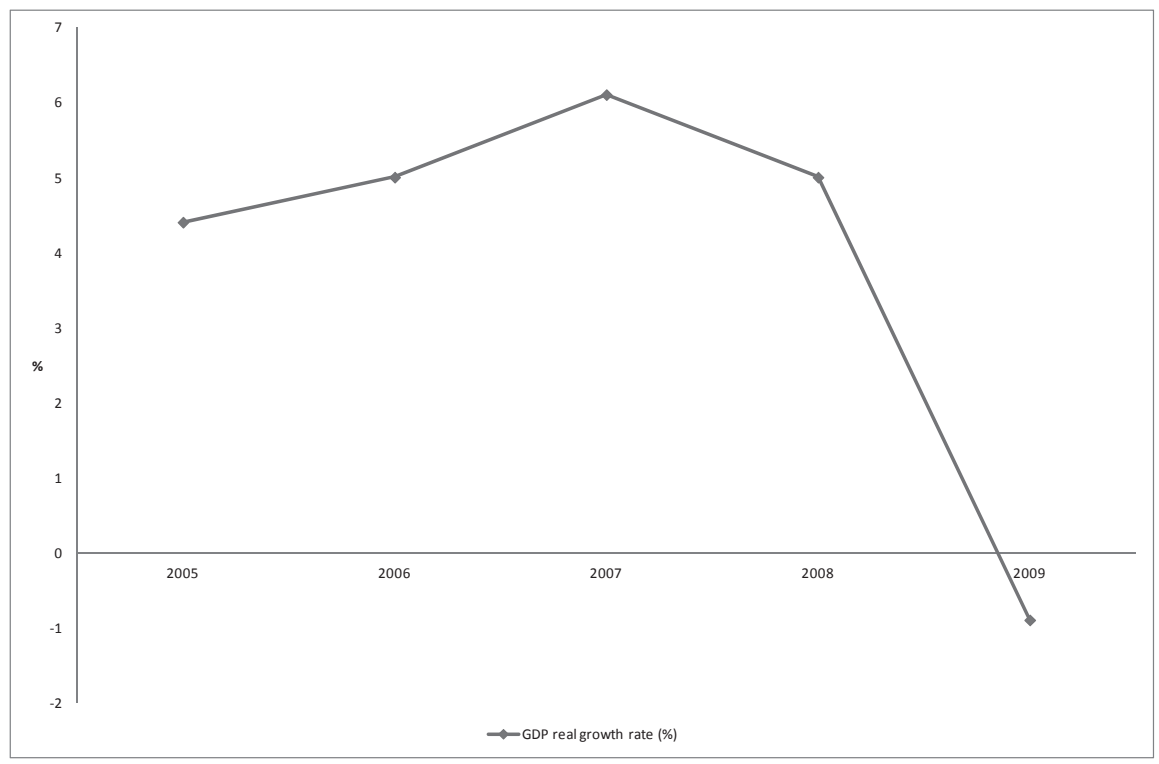

\section{Education}

The education system in a country needs to be set up in a way that will serve the labour market and respond to its needs and demands. Every mismatch between these two things should be corrected appropriately and provide positive benefits for both sides.

Until recent years, there has been a serious mismatch between labour market demand and labour market supply. Many of the skills that the labour market requires, people do not have. Some arguments explaining this situation state that teaching staff do not have appropriate practical experience and that education programmes are oriented too much towards theory instead of the gaining of practical skills. There are plenty of people that lack the contemporary skills and knowledge demanded on the job market.

Table 8 shows that most of the unemployed in the country are long-term unemployed. Almost $90 \%$ of those unemployed are people that have not been able to find a job in more than one year. This shows the lack of appropriate qualification and prequalification programmes, as well as the lack of appropriate formal education. Additionally, the more people wait to find a job, the more they lose their competitiveness because of the new trends and requirements on the labour market. 
Table 8 - Unemployed people by duration of unemployment (2009)

\begin{tabular}{|l|c|c|c|c|c|}
\hline & $\mathbf{2 0 0 5}$ & $\mathbf{2 0 0 6}$ & $\mathbf{2 0 0 7}$ & $\mathbf{2 0 0 8}$ & $\mathbf{2 0 0 9}$ \\
\hline Total & $\mathbf{1 0 0 . 0}$ & $\mathbf{1 0 0 . 0}$ & $\mathbf{1 0 0 . 0}$ & $\mathbf{1 0 0 . 0}$ & $\mathbf{1 0 0 . 0}$ \\
\hline Up to 1 month & 2.0 & 2.2 & 2.3 & 3.5 & 3.3 \\
\hline 2-5 months & 5.1 & 5.5 & 6.2 & 6.4 & 8.0 \\
\hline 6-11 months & 6.1 & 6.0 & 6.6 & 5.2 & 6.8 \\
\hline 12-17 months & 6.0 & 5.4 & 5.7 & 5.3 & 5.9 \\
\hline 18-23 months & 4.9 & 3.9 & 4.6 & 4.2 & 4.1 \\
\hline 2 years & 0.9 & 0.9 & 0.8 & 0.8 & 0.7 \\
\hline 3 years & 9.5 & 9.8 & 8.8 & 7.5 & 7.3 \\
\hline 4 years and longer & 65.4 & 66.4 & 65.0 & 67.1 & 63.8 \\
\hline
\end{tabular}

Source: Labour Force Survey, 2009, State Statistical Office, Republic of Macedonia

Figure 7 - Unemployment, by duration

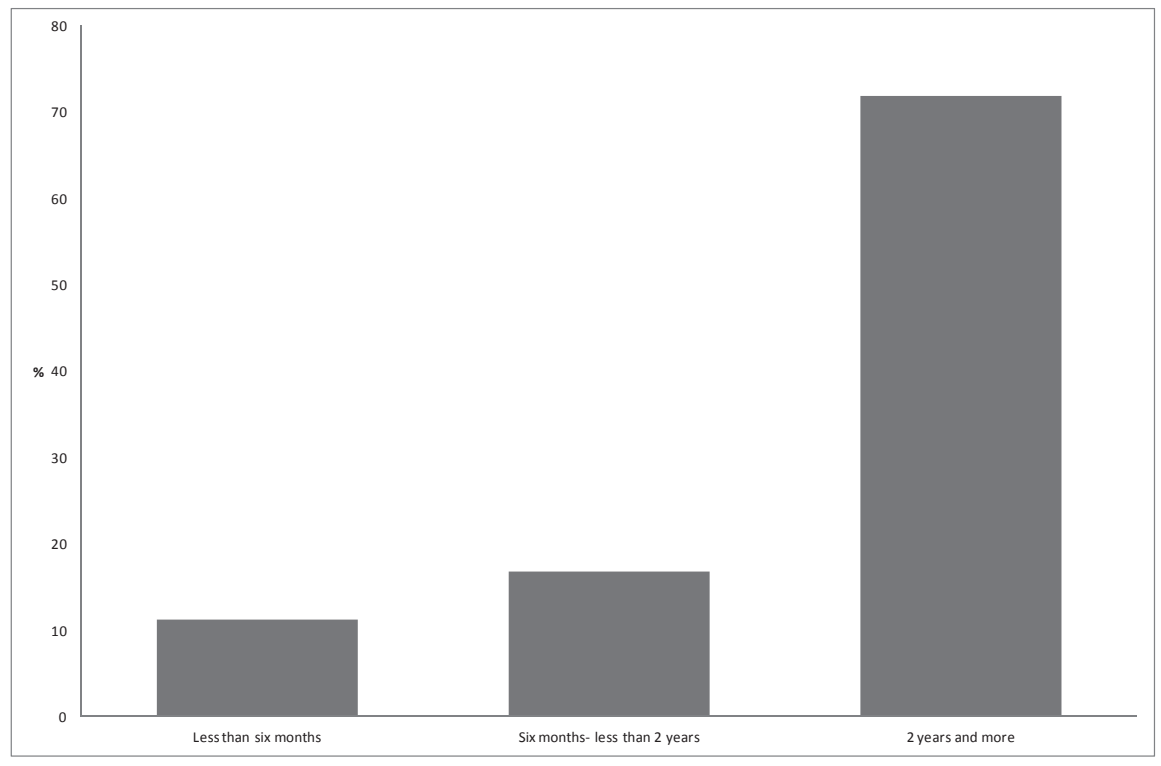

Another serious problem that Macedonia is facing is the so-called 'brain drain'. Many highly-educated young people decide to leave the country in their pursuit of a better life and job opportunities. This phenomenon takes away great potential for the economic growth of the country. Each year, the World Economic Forum issues a Global 
Competitiveness Report that reflects the productivity and competitiveness of each country in the world. One of the indicators that this report measures is the 'brain drain'. In the latest report (Global Competitiveness Report 2011-2012), Macedonia ranks $133^{\text {rd }}$ out of 142 countries. This highly negative result confirms that the young population do not believe in the opportunities that the Macedonian job market might offer them. However, we have to mention that almost all the countries of south-eastern Europe rank similarly to Macedonia.

Taking this negative situation into consideration, over the past five years Macedonia has introduced some major reforms in its education system. According to the national government, these reforms have been undertaken for the purpose (among others) of improving the quality of the labour force in Macedonia and, by doing so, increasing the competitiveness and productivity of the Macedonian economy.

The budget resources allocated to education have been significantly increased, rising from $3.5 \%$ to $5.9 \%$ of GDP in 2008. Many activities have been implemented, such as the dispersal of studies throughout the country; mandatory high school education; the study of two foreign languages in elementary school (one starting from first grade); the establishment of new education institutions for the purpose of bringing education closer to the people; the encouragement of internship programmes; free textbooks for elementary and high school students; implementing different qualification and prequalification programmes; etc.

Unfortunately, the collaboration between education institutions and the private sector is far from satisfactory. The appropriate link between theory and practice has not yet been established. Many employers are not satisfied with the practical skills possessed by graduates. Among the key requirements of Macedonian companies are for candidates to have relevant work experience and be familiar with at least one foreign language.

Furthermore, it has been recorded that employers need people that have basic computer skills. The government has tried to address this issue by providing computer courses for every Macedonian citizen and a voucher for purchasing a new computer for every senior student. Also, a major project named 'a computer for every child' has been implemented in which 100000 computers have been purchased for students in every elementary and high school in Macedonia. This is a significant number, bearing in mind that Macedonia has only two million inhabitants.

Regarding the need for workers with specific qualifications and skills, we might say that systems and IT engineers are most in demand on the job market. These professions are not only competitive with respect to labour demand, but also to wages. The government is trying to address this issue by opening new education institutions related to technology, increasing student enrolment quotas in existing institutions, providing dispersed studies throughout the country, raising the awareness of the gap, etc. Some of the companies that demand this kind of labour have even started to recruit students during the period of their studies. The good news is that the Macedonian State Statistical Office has recorded an increased number of enrolled students in the area of informatics; nevertheless, the results cannot yet be evaluated yet, since this is a long-term process and it only started a few years ago. 
In order to comprehend the rationale of introducing these 'structural' reforms into the education system in Macedonia, we outline several objectives that the Macedonian government has taken into consideration:

- decreasing school dropout rates

- increasing the number of students enrolled in higher education

- improving the quality of education at all levels

- strengthening lifelong learning and informal education

- decreasing the 'brain drain'.

\section{Employment programmes and labour market institutions}

\section{Active and passive labour market policies}

As part of the government programme for 2008-2012, the state institutions concerned have prepared several documents such as national action plans, annual operational programmes for employment, national strategies for employment, etc. In each of these documents, the activities are defined with a clear distinction between the institutions responsible and concerning the delegation of tasks. In order to implement the activities foreseen in these documents, an operational plan for the government's active programmes and measures has been prepared for each year. The operational plan is managed by the Minister for Labour and Social Policy, while the co-ordinator is the director of the Employment Agency of the Republic of Macedonia.

The programmes and measures in the operational plans tend to be similar, so here we present the operational plan for the government's active programmes and measures in $2010:^{2}$

- self-employment programme. The objective of this programme is the opening of 700 new businesses with at least one employee. This programme has been already running for several years. Each participant is part of a training initiative geared towards starting a business and developing a business idea, and has the opportunity to receive a subsidy worth $€ 3000$ to start a business. A specific target group is eligible to apply for this programme, i.e: people who have been unemployed for more than six months; young people up to 27 years old that have been unemployed for more than three months; and unemployed Roma people

- support for formalising existing businesses. The objective of this programme is the formalisation of 250 new businesses with at least one employee. This measure is part of the government's fight against the grey economy. The idea is for those who are officially unemployed to legalise their businesses and become part of the official economy. The envisaged subsidy amounts to $€ 3000$

- pilot support for additional hiring in companies registered through the self-employment programme in 2007 and 2008. For this programme, eligibility is directed towards those companies that have received a subsidy through the self-employment programme and that have positive financial results. For each new job opened as a

2 All of the measures, activities and programmes listed here are drawn from the operational plan for the government's active programmes and measures in 2010. 
result of this programme, companies have the opportunity to receive a $€ 1500$ subsidy

- entrepreneurship promotion through existing business incubators and training for skills in high demand on the job market. The purpose of this programme is to support export-oriented companies that use ICT. Thirty beneficiaries are targeted, each of which will receive training in product design and 3D design

- preparation for employment. Activities such as qualifications, pre-qualification, counselling, etc. are foreseen within this programme, which can be subdivided into five measures:

- training, qualification and pre-qualification for a known employer. With this measure, the Agency for Employment of the Republic of Macedonia is seeking to help employers train new employees (if there are no unemployed people with those particular skills). The new employees receive a certain level of compensation from the Agency during the training period

- training related to foreign languages and computer skills. These training initiatives are carried out by unemployed people for a certain amount of compensation

- pilot training initiatives for the study of the English language for the catering industry. Here, the trainers are unemployed people that receive compensation for their engagement

- training initiatives for skills which are in high demand on the labour market. These initiatives refer to specific skills, such as those of an electrician in apartment buildings, a gastronomist, etc.

- training initiatives related to informatics. Each of the participants in these initiatives receives a certificate upon completion of the training.

- Training initiatives related to starting a business.

- subsidising employment. Under this programme, financial support is foreseen for those employers interested in hiring people that belong to one of the following groups: unemployed people with orphan status; people with disabilities; single parents; couples with three or more children; parents of children with disabilities; unemployed people aged between 55 and 64 years of age; unemployed people younger than 27; unemployed people that have lost their job due to insolvency or liquidation; and victims of domestic violence

- internship programme. The objective of this programme is to stimulate internship opportunities for unemployed people younger than 27. Financial support is provided for the interns

- polling for available vacancies. The idea is to gather relevant data about the labour market situation. To implement this activity, unemployed people will be engaged who will receive a certain amount of compensation for their activities

- support for women that are victims of domestic violence. Different support activities are foreseen for this target group, such as subsidies, self-employment, qualification and pre-qualification

- support for Roma people. Training initiatives for Roma people related to specific skills (such as plastering) are foreseen. 
For the implementation of the 2010 operational plan, $€ 8.5 \mathrm{~m}$ is needed. Most of the resources are provided by government institutions, while the rest is from different donor organisations.

A very important passive policy that has not been mentioned in the operational plan is that of severance payments, i.e. one of the 'cures' of the consequences when someone remains jobless. The Law on Labour Relations outlines several obligations when someone remains jobless due to redundancy (because of technological, economic, organisational or other similar changes). If a person is dismissed due to any of these reasons, the employer might offer the redundant employee one of the following:

- to provide employment for that person with another employer under a joint agreement in which the working activities will be according to that person's skill level

- to provide qualification and pre-qualification programmes in order to work for the same or another employer

- to provide a new employment contract.

Related to severance pay, if a person is dismissed due to redundancy, the employer has the following obligations:

- for a person with up to five years experience, the employer needs to provide a severance payment of one net wage

- for a person with five to ten years experience, the severance payment is for two net wages

- for a person with ten to fifteen years experience, it is three net wages

- for a person with fifteen to twenty years experience, four net wages

- for a person with twenty to 25 years experience, five net wages

- for a person with more than 25 years experience, the payment is six net wages.

When calculating the net wage, the employer needs to take into consideration the net wage the employee has been receiving in the last six months before being dismissed. However, this amount must not be less than $50 \%$ of the average net wage in Macedonia.

The individual's work experience covers the full employment record, i.e. with all employers, but it is the most recent employer who has the obligation to cover the costs of severance pay.

An additional measure that needs to be mentioned is that severance pay for people who have less than five years left before retirement (i.e. men at the age of 64, women at the age of 62). If such a person is dismissed due to redundancy, this person, in the first year after being dismissed, will receive $50 \%$ of the net wage and after that up until retirement, $40 \%$ of the net wage. In some cases, if the company is doing well and has high levels of profit, the company covers the other $50 \%$ / $60 \%$ until retirement.

\section{Economic and Social Council}

The Economic and Social Council (ESC) was established in Macedonia as far back as 1996. However, it has never started to play its proper role. The reasons for this are that, at that time, the structure of trade unions and their role was not clear; furthermore, it seemed that the government authorities lacked an interest in getting the organisation going. 
In order to improve social dialogue in the country, the government decided to reconstitute the Economic and Social Council on 25 August 2010 following an agreement with the social partners, such as the representative trade unions and employers associations in the Republic of Macedonia. Over the last few years, Macedonia had been criticised by the European Union with respect to this issue. In order to improve this situation, the authorities have made certain changes to the Law on Labour Relations in relation to defining the criteria for an organisation to be representative of trade unions or an employer association. All of these conditions were met, so the Economic and Social Council of Macedonia was established once more.

Each of the three parties has four members of the ESC while the Chair is the Minister for Labour and Social Policy. The idea is to put in place a dialogue that will reflect, or at least take into consideration, public attitudes (from employees or employers) towards a certain policy and its economic or social impact. This body will be consulted for the preparation and implementation of economic and social strategies and policies.

According to the Agreement for the Establishment of the Economic and Social Council, the ESC is to provide recommendations and opinions on the following topics: $^{3}$

- economic development

- labour market policies

- wage and price-related policies

- labour and social insurance

- social protection

- health protection

- environment

- fiscal policy

- working conditions and protection

- education, culture and professional improvement

- other areas that influence the economic and social interests of employees and employers.

\section{Conclusion}

When analysing this article, the contradictions are evident. On the one hand, there are plenty of measures and policies that are being introduced to improve the labour market situation but, on the other, Macedonia's results with respect to unemployment are highly negative. To explain this situation, we must consider the reasons for the labour market conditions that have been mentioned and the durability of the process of decreasing unemployment. Many of the measures are expected to have long-term effect and, therefore, the results might not yet be visible.

It is apparent that the Macedonian labour market is experiencing serious difficulties and, besides the existing policies and measures, it is clear that improving the quality of the workforce, increasing employment opportunities and dealing with the regional dimension will be critical to the country's growth. These are just a small part of what

3 The topics are divided as stated in the Agreement for the Establishment of the Economic and Social Council. 
needs to be introduced. However, there are many successful examples and best practices that can be followed. With a proactive approach and a real concern for the issues that trouble us, the objective of decreasing unemployment and promoting economic growth can be achieved.

\section{References}

Centre for Research and Policy Making (2009) How to Improve the Quality of Higher Education.

Department of Enterprise Trade and Employment (Republic of Ireland) (2003) $\mathrm{Na}$ tional Employment Action Plan Ireland 2003-2005.

Government of Republic of Macedonia (2006) National Employment Strategy 2010.

Kostadinov, Aleksandar (2009) Labour market policies in Macedonia Centre for Economic Analyses (CEA).

Ministry for Finance Macroeconomic Policy of the Republic of Macedonia 2011.

Ministry for Labour and Social Policy Operational Plan for Active Employment Programmes and Measures 2010.

Ministry for Labour and Social Policy and Ministry for Education and Science (2006) Operational Programme for IPA 'Human Resources Development 2007-2013'.

Official Gazette of the Republic of Macedonia Law on Labour Relations No. 158, 9 December 2010.

Republic of Macedonia Agreement for the Establishment of the Economic and Social Council.

State Statistical Office of the Republic of Macedonia Employees and Net Wages Status October 2010 -.

State Statistical Office of the Republic of Macedonia Labour Force Survey, 2009.

State Statistical Office of the Republic of Macedonia News releases related to the labour market www.stat.gov.mk

State Statistical Office of the Republic of Macedonia (2009) Regions of the Republic of Macedonia, 2009 Second edition.

World Economic Forum Global Competitiveness Report 2011-2012. 